\title{
MORPHOMETRIC CHARACTERISTICS OF CATFISH Silurus triostegus (Heckel, 1843) FROM THE TIGRIS AND SHATT AL-ARAB RIVERS, IRAQ
}

\author{
Laith A. Jawad ${ }^{1 *}$, Muhammad I. G. Al-Janabi ${ }^{2}$ \\ ${ }^{1}$ Flat Bush, Manukau, Auckland, New Zealand \\ ${ }^{2}$ Iraq Natural History Research Centre and Museum, University of Baghdad, Baghdad, Iraq \\ *Corresponding Author, Email: Iaith_jawad@hotmail.com
}

\section{ARTICLE INFO \\ Received: 29 March 2016 \\ Received in revised form: 25 July 2016 \\ Accepted: 10 September 2016 \\ Available online: 21 September 2016}

\author{
Keywords: \\ Freshwater \\ Siluridae \\ Morphometric characters \\ Management \\ Environment \\ Body form
}

\begin{abstract}
Thirteen morphometric characters of catfish Silurus triostegus were studied from three localities on the Tigris and Shatt al-Arab rivers, Iraq. Monthly samples revealed no significant differences between genders. Positive allometric growths for all morphometric characters studied were observed. This study gives information to fishery biologists about morphometric characters of S. triostegus from the Tigris and Shatt al-Arab rivers to assist in planning of conservation strategies for this fish species.
\end{abstract}

How to Cite

Jawad, L. A., Al-Janabi, M. I. G. (2016): Morphometric characteristics of catfish Silurus triostegus (Heckel, 1843) from the Tigris and Ahatt al-Arab rivers, Iraq. Croatian Journal of Fisheries, 74, 179-185. DOI: 10.1515/cjf2016-0021.

\section{INTRODUCTION}

Catfishes in the Mesopotamian Tigris-Euphrates basin are representatives of both European and southern Asian species, with a mixed fauna of low endemicity, leading to questions such as the phylogenetic distinctness of this group of species for the region. Some examples of controversy include the phylogeny of catfishes of the genus Silurus. Silurus chantrei has been classified as a synonym for $S$. asotus from the Far East. Similarly, S. triostegus in Mesopotamia has been suggested to be a variant of S. glanis (Hora and Misra, 1943), indicating that there are still several questions regarding phylogenetic relationships for this group in the Middle East. Investigations of the morphometric characteristics of $S$. triostegus may provide a first step in resolving some of the phylogeny of this ecologically important species for
Mesopotamian ecosystems.

S. triostegus occurs in the Tigris-Euphrates basin, mostly restricted to Iraq, Iran, Turkey and Syria (Ünlü and Bozkurt, 1996; Najafpour, 1997; Abdoli, 2000; Esmaeili et al., 2010,; Coad, 2010; Ünlü et al., 2012). In Iraq, it inhabits open vegetated lakes, marshes and rivers (Van den Eelaart, 1954), especially in the southern marshes of Iraq (Hussain and Ali, 2006). An increase in the biomass of this species occurred after recent declines in predatory otter and aquatic bird populations inhabiting marsh areas of southern Iraq (Hussain et al., 2008). Similarly, distribution and abundance of $S$. triostegus populations in other parts of Iraq have been affected by dam construction, causing shifts in salinity and pollution increase (Hashemi et al., 2012).

Among several taxonomic methods for identifying fish, morphometric techniques are more suited to be used in the 
field. There are several morphometric characters that reflect ecophenotypic variation and are commonly used in biometric and population identification studies, including body length and width, and length of other body parts (Waldman, 2005). Moreover, morphometric techniques are preferred over their molecular counterparts when it comes to cost, making it even more suitable when large quantities of fish are to be identified, as is common in field studies. Diversity studies based on morphometrics, therefore, may prove essential in determining key areas for conservation and management. In the light of the need for conservation and promise of morphometric tools to estimate biodiversity, this study presents some morphometric parameters of catfish S. triostegus from three populations in the Tigris and Shatt al-Arab rivers, Iraq.

\section{MATERIALS AND METHODS}

In Mesopotamia, the Tigris and Euphrates rivers are the largest. The Tigris River extends for $1,850 \mathrm{~km}$, starting from the Taurus Mountains in eastern Turkey to the coast of Iraq. Several tributaries join this river along its north-south flow in Iraq (Isaev and Mikhailova, 2009). The Shatt al-Arab River is formed by the confluence of the Tigris and Euphrates rivers at al-Qurnah, Basrah Governorate, south Iraq. It is $200 \mathrm{~km}$ long and varies in width between 230 meters at Basrah City to 800 meters at its mouth in Arabian/Persian Gulf (Country data. com, 2015). Sample stations at Al-Qurnah, Basrah City and at the river's mouth were chosen for this study.

Fish samples were obtained from fishers operating near the sampling sites. Samples were collected in August 2004. One thousand two hundred individuals of $S$. triostegus were obtained. Three hundred and fifty, ranging in total length from 200 to $500 \mathrm{~mm}$, of which 200 were females and 150 males, were obtained from Mosul. Four hundred and fifty, ranging in total length from 210 to $400 \mathrm{~mm}$, of which 350 were females and 100 males, were obtained from Baghdad. Four hundred, ranging in total length from 200 to 320 mm, of which 300 were females and 100 males, were sampled in the Basrah area. Fish were examined while still fresh. Total length $(\mathrm{TL})$, standard length (SL), head length $(\mathrm{HL})$, head depth (HD), eye diameter (ED), preorbital length (ProL), postorbital length (PosL), upper jaw length (UJL), lower jaw length (LJL), pectoral fin length (PFL), pelvic fin length (PVFL), body depth (BD), caudal peduncle depth (CPD) were measured in $\mathrm{mm}$ using a digital calliper (Fig. 1).

Sex was determined microscopically and gender proportions analyzed using a one-way ANOVA. To eliminate scaling problems associated with growth in morphometric characters (non-discrete, measurable), each measurement was standardized. The relationship between total fish length and morphometric characters was estimated using the following formula:

$Y=a+b X$

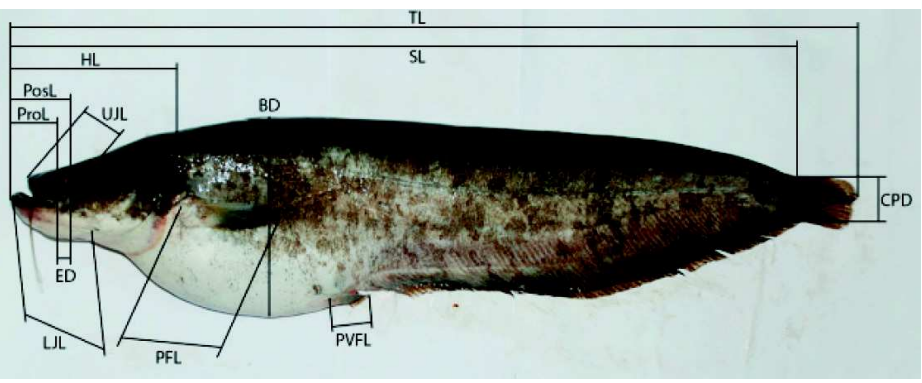

Fig 1. Morphometric characters of Silurus triostegus. BD, body depth; CPD, caudal peduncle depth; ED, eye diameter; HD, head depth; HL, head length; LJL, lower jaw length; PFL, pectoral fin length; PosL, postorbital length; ProL, preorbital length; PVFL, pelvic fin length; SL, standard length; TL, total length; UJL, upper jaw length (photo by Muhammad I. G. Al-Janabi)

Where, $\mathrm{Y}=$ morphological characters; $\mathrm{X}=$ total fish length; $\mathrm{a}$, $\mathrm{b}=$ constants.

The type of allometry was evaluated by testing the allometric coefficient " $b$ " $(b=1, b>1$ and $b<1$ for isometry, negative allometry and positive allometry, respectively). Student $t_{s}$ test was used to verify whether calculated "b" was significantly different from 1 using the following formula:

$t_{\mathrm{s}}=\mathrm{b}-1 / \mathrm{sb}$

Where ts is the t-test value, $b$ is the slope and $s b$ is the standard error of the slope (b). The allometric coefficient was used to investigate the relationship between morphological characters (Van Snik et al., 1997). ANOVA was used to estimate the relationships between morphological characters and the populations represented by the fish samples taken.

\section{RESULTS}

Total length standardized morphological characters show a higher average for the Mosul population, followed by Baghdad and Basrah populations (Table 1). Analysis of variance results showed that all morphometric measurements were significantly different between the samples $(p<0.001)$. ANOVA also revealed no statistical differences between males and females for morphometric analysis $(P>0.05)$, so sexes were pooled for further analysis.

The linear regression coefficient for morphometric variables $(\mathrm{Y})$ on the total length $(\mathrm{X})$ showed the highest and lowest values for the Basrah population, where BD was estimated to be 0.339 and PVFL 0.049 .

The present study shows the highest correlation of the total length standardized morphometric characters is 0.992 for ProL for the Baghdad population and the lowest is 0.902 for LJL for the Mosul population. Growth of all morphometric characters relative to total length showed a positive allometry. The relationship between total and standard lengths was estimated to have a negative allometry and a slope of 0.988 . 


\section{DISCUSSION}

Similar research on the morphology of males and females of fishes agree with our findings on having no significant difference between sexes (Lashari et al., 2004; Narejo et al., 2000; Narejo, 2010; Dars et al., 2012). Our results also agreed with the conclusion advanced by Minos et al. (1995), Cavalcanti et al. (1999), Sabadin et al. (2010), Díaz de-Astarloa et al. (2011) and Zhan and Wang (2012) that morphometry can be used to distinguish among species of fish.
Morphological descriptors are important for taxonomic classification of organisms and estimation of species diversity (Dean et al., 2004). One of the major keys in fish biology are morphometric characters as they are important for systematics, estimation of growth variability, ontogeny (Kovac and Copp, 1999) and population-level studies (Verep et al., 2006). Variations in morphology are less obvious at the intra-specific level, whereas phenotypic variation is less obvious under genetic control and more subject to environmental influences (Clayton, 1981).

Variation in the phenology of fish allows adaptations to

Table 1. Descriptive statistics of morphometric traits of Silurus triostegus. SE, standard error; R2, correlation coefficient

\begin{tabular}{|c|c|c|c|c|}
\hline Morphometric indices & Range & Mean TL \pm SE & $Y=a+b X$ & $\mathbf{R}^{2}$ \\
\hline Total length & $200-500$ & $356 \pm 2.9$ & - & - \\
\hline Standard length SL & $180-490$ & $240 \pm 2.0$ & $S L=1.424+0.242 T L$ & 0.988 \\
\hline Head length HL & $102-110$ & $105 \pm 1.9$ & $\mathrm{HL}=1.424+0.242 \mathrm{TL}$ & 0.982 \\
\hline Head depth HD & $34-36$ & $35 \pm 2.1$ & $\mathrm{HD}=-2.432+0.203 \mathrm{TL}$ & 0.950 \\
\hline Eye diameter ED & $30-35$ & $32 \pm 0.9$ & $E D=1.152+0.053 \mathrm{TL}$ & 0.932 \\
\hline Preorbital length ProL & $28-30$ & $28 \pm 1.3$ & ProL $=-1.973+0.107 \mathrm{TL}$ & 0.972 \\
\hline Postorbital length PosL & $44-45$ & $41 \pm 1.6$ & PosL $=0.736+0.108 \mathrm{TL}$ & 0.960 \\
\hline Upper jaw length UJL & $15-17$ & $16 \pm 2.1$ & $\mathrm{UJL}=0.342+0.294 \mathrm{TL}$ & 0.956 \\
\hline Lower jaw length LJL & $19-21$ & $20 \pm 1.9$ & $\mathrm{LJL}=0.154+0.060 \mathrm{TL}$ & 0.902 \\
\hline Pectoral fin length PFL & $70-73$ & $72 \pm 2.1$ & $P F L=-1.438+0.191 \mathrm{TL}$ & 0.976 \\
\hline Pelvic fin length PVFL & $75-82$ & $77 \pm 1.2$ & PVFL $=-.0796+0.047 \mathrm{TL}$ & 0.966 \\
\hline Body depth BD & $41-52$ & $46 \pm 1.9$ & $\mathrm{BD}=-8.499+0.332 \mathrm{TL}$ & 0.974 \\
\hline Caudal peduncle depth CPD & $12-13$ & $23 \pm 2.2$ & $C P D=-5.394+0.171 T L$ & 0.971 \\
\hline Total length & $210-400$ & $320 \pm 2.1$ & - & - \\
\hline Standard length SL & $200-390$ & $293 \pm 1.4$ & $\mathrm{SL}=1.435+0.249 \mathrm{TL}$ & 0.968 \\
\hline Head length HL & $116-121$ & $117 \pm 1.9$ & $\mathrm{HL}=1.436+0.254 \mathrm{TL}$ & 0.972 \\
\hline Head depth HD & $37-39$ & $36 \pm 1.6$ & $H D=-2.442+0.213 T L$ & 0.980 \\
\hline Eye diameter ED & $37-39$ & $37 \pm 1.5$ & $\mathrm{ED}=1.164+0.060 \mathrm{TL}$ & 0.962 \\
\hline Preorbital length ProL & $33-35$ & $32 \pm 1.3$ & ProL $=-1.964+0.110 \mathrm{TL}$ & 0.992 \\
\hline Postorbital length PosL & $46-47$ & $46 \pm 1.7$ & PosL $=0.745+0.112 \mathrm{TL}$ & 0.980 \\
\hline Upper jaw length UJL & $20-35$ & $26 \pm 1.4$ & $\mathrm{UJL}=0.352+0.298 \mathrm{TL}$ & 0.986 \\
\hline Lower jaw length LJL & $25-36$ & $31 \pm 2.0$ & $\mathrm{LJL}=0.165+0.059 \mathrm{TL}$ & 0.942 \\
\hline Pectoral fin length PFL & $40-65$ & $52 \pm 2.2$ & $P F L=-1.441+0.190 \mathrm{TL}$ & 0.986 \\
\hline Pelvic fin length PVFL & $25-36$ & $30 \pm 1.9$ & PVFL $=-.0798+0.051 \mathrm{TL}$ & 0.976 \\
\hline Body depth BD & $62-71$ & $65 \pm 1.2$ & $\mathrm{BD}=-8.498+0.334 \mathrm{TL}$ & 0.984 \\
\hline Caudal peduncle depth CPD & $14-15$ & $13 \pm 1.3$ & $C P D=-5.396+0.171 T L$ & 0.981 \\
\hline Total length & $200-320$ & $298 \pm 2.0$ & - & - \\
\hline Standard length SL & $185-310$ & $265 \pm 2.1$ & $S L=1.430+0.248 T L$ & 0.978 \\
\hline Head length HL & $127-144$ & $134 \pm 1.9$ & $\mathrm{HL}=1.428+0.248 \mathrm{TL}$ & 0.962 \\
\hline Head depth HD & $40-45$ & $4.3 \pm 1.8$ & $\mathrm{HD}=-2.436+0.207 \mathrm{TL}$ & 0.960 \\
\hline Eye diameter ED & $42-53$ & $46 \pm 2.0$ & $E D=1.159+0.059 T L$ & 0.940 \\
\hline Preorbital length ProL & $37-39$ & $37 \pm 1.5$ & ProL = -1.977 + 0.109 TL & 0.979 \\
\hline Postorbital length PosL & $48-52$ & $49 \pm 1.1$ & PosL $=0.738+0.109 \mathrm{TL}$ & 0.966 \\
\hline Upper jaw length UJL & $42-48$ & $44 \pm 1.8$ & $\mathrm{UJL}=0.348+0.299 \mathrm{TL}$ & 0.959 \\
\hline Lower jaw length LJL & $40-48$ & $44 \pm 1.9$ & $\mathrm{LJL}=0.157+0.062 \mathrm{TL}$ & 0.952 \\
\hline Pectoral fin length PFL & $20-38$ & $29 \pm 3.0$ & $P F L=-1.439+0.197 \mathrm{TL}$ & 0.978 \\
\hline Pelvic fin length PVFL & $19-21$ & $20 \pm 2.4$ & PVFL $=-.0799+0.049 \mathrm{TL}$ & 0.967 \\
\hline Body depth BD & $75-81$ & $78 \pm 2.6$ & $B D=-8.501+0.339 T L$ & 0.979 \\
\hline Caudal peduncle depth CPD & $16-17$ & $16 \pm 1.9$ & $C P D=-5.398+0.179 T L$ & 0.978 \\
\hline
\end{tabular}


environmental change by adjustment of their physiology and behaviour to effects of environmental variation, which leads to changes in morphology, reproduction and survival (Stearns, 1983; Meyer, 1987). Variation in morphological characters due to changes in the environmental factors may be preferred for stock identification, especially when the timescale is inadequate for important genetic differentiation of population, such as may happen for partially isolated stocks.

Sfakianakis et al. (2011) and Georgakopoulou et al. (2007) have found that morphometric characters of Danio rerio changed with water temperature, which may influence fish metabolism through changes in dissolved oxygen (Wimberger, 1992). Our results showed that S. triostegus was larger in the Tigris River at Mosul City and smaller in populations from the Shatt al-Arab River. In the populations of the Tigris River at Baghdad City, the size of fishes was in between. Water temperature at Mosul was lower (8 to 18 C) than that in Baghdad ( 15 to 25 C) and Basrah City (20 to 40 C; Al-Sanjari and Al-Tamimi, 2009; Al-Noor et al., 2013). In Turkey, further to the north of Iraq, water temperature is lower than in the Tigris River at Mosul. Individuals of $S$. triostegus obtained there were much larger than those obtained from the north of Iraq. This decrease in water temperature toward the north explains the relationship of water temperature with size of the fish. Similar conclusion was reached by Atkinson (1994), Haddon and Willis (1995), and Emmrich et al. (2014). Water temperature seems not to affect only body size but other morphometric characters like head length and depth, body depth and caudal peduncle depth (Georgakopoulou et al., 2007; Eagderi et al., 2015). Low water temperature increases water viscosity and density and, thus, changes of body shape towards a more fusiform body are advantageous to decrease drag (Wimberger, 1992). Hence, physicochemical features of aquatic ecosystems change with water temperature and, therefore, fish will respond with new variations in body shape (Sfakianakis, 2011).

Rowiński et al. (2015) provided an explanation for the deep body and caudal peduncle of fish by which they suggested that the effect of water temperature and food was responsible for such changes. They concluded that high temperatures elevate metabolism and feeding activity (Claireaux and Lagardere, 1999; Sunuma et al., 2007; Arula et al., 2012; Slavik and Horky, 2012), which may lead to higher growth rates in fish. When food becomes abundant, the surplus of food taken can be allocated to somatic growth. Consequently, differentiation in different parts of the fish becomes obvious (Kemp and Bertness, 1984; Lindsey, 1988; Pelletier et al., 1994). Therefore, it is difficult to differentiate between the effect of temperature and food consumption as both are interconnected. This is in agreement with the results obtained here. Individuals of S. triostegus from the Shatt al-Arab River at Basrah City were shown to have deeper body than those from the Tigris River at Mosul City. Population from the Tigris River at Baghdad City showed a value in between. This is also true for caudal peduncle depth, and head length and depth. The same can be stated for the effect of water current on body shape, as stated above for the effects on shape from water temperature (Esmaeili et al., 2011; Sajina et al., 2013).

The noticeable growth in the abdominal region of the target species suggests greater development of the intestine (Elbal et al., 2004), a finding corroborated by other studies that have shown that the middle part of the body increases throughout ontogeny (after head and tail) in bilateral species (Osse et al., 1997; van Snik et al., 1997; Gozlan et al., 1999) later than in asymmetrical species (Paralichthys californicus, Gisbert et al., 2002).

Samaee and Patzner (2010) have suggested that feeding regime could affect head morphology, including mouth size and the length of upper and lower jaw. Prey size is another factor that may affect the proximity of the eyes and both the preorbital and postorbital lengths (Costa et al., 2003; Turan, 2004). The population of S. triostegus from the Shatt al-Arab River has a large mouth, including the upper and lower jaws. Such modification favours ingestion of large and hard prey, such as crabs and some fish species that are available in the Shatt al-Arab River environment (Naderloo and Schubart, 2009; Naderloo, 2011). In contrast, individuals of this species from the Tigris River at Mosul showed smaller mouth and jaws, which are adapted to the feeding habits of species inhabiting running waters. The water of the Shatt al-Arab River is turbid due to the muddy substrate (Alaamer, 2015) and the presence of fish species with bottom feeding habits (Hussein et al., 2000a, $2000 b)$. In such a habitat, the variation in eye diameter can be attributed to the developmental adaptation in fishes during their early stages inhabiting low light intensity, due to low turbidity (Matthews, 1988). Masuda and Tsokamoto (1996) noted that some morphological development happened in the eye as a function of light intensity. Higgs and Fuiman (1996) analysed the relation between eye diameter and light intensity for schooling behaviour in several species. Miyazaki et al. (2000) reported similar results for Pseudocaranx dentex. Solar absorption reduces from the north to the south of the Shatt al-Arab River as the bottom changes to silt and mud, and the density of aquatic plants increases. Such gradient in sunlight absorption has also been observed by Kumar et al. (2010) in the Bay of Bengal due to large quantities of sediment influx. Hence, the variation in eye diameter in fishes from north to south in Iraq can perhaps be attributed to the variation in light penetration.

The active swimmer fish that searches for food and lives in running water usually has longer fins, in addition to a shallower body (McLaughlin and Grant, 1994; Liao, 2007). Such conditions agree with the results obtained in this 
study, where individuals with longer pectoral and pelvic fins from the Tigris River at Mosul City and shorter fins in individuals in the Shatt al-Arab River were found. Fin lengths for the population in the Tigris River at Baghdad City were between those from the Mosul and Basrah localities.

In the present study, all morphometric measurements were highly correlated (above 0.9). This indicates that the growth of $S$. triostegus in one area of the body is related to the growth in another area. Oniye et al. (2006) and Safie et al. (2014) obtained similar results for Protopterus annectens and Pomadasys stridens, respectively.

The analysis of morphometric characters obtained in this study shows that there are three morphologically distinct populations of S. triostegus in the Tigris and Shatt al-Arab rivers, and that these differences may be due to body shape and not size. Morphological characters were used in this work to make essential information about the differences between the populations of $S$. triostegus in the Tigris and Shatt al-Arab rivers available. This information may be used in developing management strategies for the study area in the future. Ecological factors may be drivers for such variations, as has been shown for other fish species (Clayton, 1981; Esmaeili et al., 2011). Future studies confirming our findings on the populations of $S$. triostegus in the Tigris and Shatt al-Arab rivers using molecular markers should be considered.

\section{ACKNOWLEDGEMENTS}

Our sincere thanks are due to Ralf Riedel, Centre for Fisheries Research and Development, Gulf Coast Research Laboratory, University of Southern Mississippi, USA for reading the manuscript. To Joacim Näslund, Zoologihuset, Göteborgs Universitet, Göteborg, Sweden for editing the fish images with Photoshop.

\section{Sažetak}

\section{MORFOMETRIJSKA OBILJEŽJA SOMA Silurus triostegus (Heckel, 1843) IZ RIJEKA TIGRIS I SHATT AL-ARAB U IRAKU}

Trinaest morfometrijskih obilježja soma Silurus triostegus su istraživana na tri lokacije u rijekama Tigris i Shatt al-Arab u Iraku. Mjesečni uzorci su pokazali da nema značajne razlike između spolova. Zabilježen je pozitivan alometrijski rast za sva istraživana morfometrijska obilježja. Ova studija daje znanstvenicima informacije o morfometrijskim obilježjima S. triostegus iz rijeka Tigris i Shatt al-Arab kao pomoć pri planiranju strategija očuvanja za ovu riblju vrstu.

Ključne riječi: slatke vode, Siluridae, morfometrijska obilježja, upravljanje, okolina, oblik tijela

\section{REFERENCES}

Abdoli, A. (2000): The Inland Water Fishes of Iran. Iranian Museum of Nature and Wildlife, Tehran. 378 pp. In Farsi.

Alaamer, H. A. (2015): Characteristics of sub-bottom profile acquired in Shatt al-Arab River, Basrah-Iraq. International Journal of Marine Science, 5, 1-6.

Al-Noor, T. A., Arslan, L. K., Abd Ali, L. J. (2013): Studying the effects of Industrial Wastes on Tigris water in Al- Great City-Baghdad-Iraq. Advances in Physics Theories and Applications, 25, 48-57

Al-Sanjari, M. N., Al-Tamimi, M. A. (2009): Interpretation of Water Quality parameters for Tigris River within Mosul City by Using Principal Components Analysis. Tikrit Journal of Pure Science, 14, 1-6

Arula, T., Kotta, J, Lankov, A., Simm, M., Polme, S. (2012): Diet composition and feeding activity of larval springspawning herring: importance of environmental variability. Journal of Sea Research, 68, 33-40.

Atkinson, D. (1994): Temperature and organism size: a biological law for ectotherms? Advances in Ecological Research, 25, $1-58$.

Cavalcanti, M. J., Monteiro, L. R., Lopes, P.R.D. (1999): Landmark-based morphometric analysis in selected species of serranid fishes (Perciformes: Teleostei). Zoological Studies, 38, 287- 294.

Clayton, J.W. (1981): The stock concept and the uncoupling of organismal and molecular evolution. Canadian Journal of Fisheries and Aquatic Sciences, 38, 1515 - 1522.

Claireaux, G., Lagardere, J. P. (1999): Influence of temperature, oxygen and salinity on the metabolism of the European sea bass. Journal of Sea Research, 42, 157-168.

Coad, B.W. (2010): Freshwater fishes of Iraq. Pensoft Series Faunistica No. 93, 274 pp. Pensoft Publishers, Moscow.

Costa, J. L., Al-meida, P. R., Costa, M. J. (2003): Amorphometric and meristic investigation of Lusitanian toadfish Halobatrachus didactylus (Bloch \& Schneider, 1801): evidence of population fragmentation on Portugese coast. Scientia Marina, 67, $219-231$.

Country data.com (2015): Iraq - Major Geographical Features. country-data.com. (Cited 12 December 2015).

Dars, B. A., Narejo, N. T., Awan, K. P. (2012): Morphometric, meristic characters and their relationship in Channa punctatus (Bloch) from River Indus, Sindh, Pak. Sindh University Research Journal (Sci: Ser), 44, 91-96.

Dean, C. A., Rholf, F.J., Dennis, E.S. (2004): Geometric morphometrics: ten years of progress following the revolution. Italian Journal of Zoology, 71, 5-16.

Díaz de Astarloa, J.M., Bezzi, S., González-Castro, M., Mabragaña, E., Hernández, D., Delpiani, S.M. (2011): Morphological, morphometric, meristic and osteological evidence for two species of hake (Actinopterygii: Gadiformes: Merluccius) in Argentinean waters. Journal of Fish Biology, 78, 1336-1358. 
Eagderi, S., Poorbagher, H., Parsazade, F., Mousavi-Sabet, H. (2015): Effects of rearing temperature on the body shape of swordtail (Xiphophorus hellerii) during the early development using geometric morphometrics. Poeciliid Research, 5, 24-30.

Elbal, M. T., García Hernández, M.P., Lozano, M.T., Agulleiro, B. (2004): Development of the digestive tract of gilthead sea bream (Sparus aurata, L.). Light and electron microscopic studies. Aquaculture, 234, 215-238

Emmrich, M., Pédron, S., Brucet, S., Winfield, I.J., Jeppesen, E., Volta, P., Argillier, C., Lauridsen, T. L., Holmgren, K., Hesthagen, T., Mehner, T. (2014): Geographical patterns in the body-size structure of European Lake fish assemblages along abiotic and biotic gradients. Journal of Biogeography, 41, 2221-2233

Esmaeili, H.R., Coad, B.W., Gholamifard, A., Nazari, N., Teimori, A. (2010): Annotated checklist of the freshwater fishes of Iran. Zoosystematica Rossica, 19, 361-386.

Esmaeili, H.R., Nazari, N., Saifi, M., Gholamhosseini, A. (2011): Morphometric and meristic comparisons of populations of Qanat tailor fish, Alburnoides qanati Coad \& Bogutskaya, 2009 (Actinopterygii: Cyprinidae) in Khor River basin, Ira. Iranian Journal of Animal Biosystematics, 7, 1-11.

Georgakopoulou, E., Sfakianakis, D. G., Kouttouki, S., Divanach, P., Kentouri, M., Koumoundouros, G. (2007): The influence of temperature during early life on phenotypic expression at later ontogenetic stages in sea bass. Journal of Fish Biology, 70, 278-291.

Gisbert, E., Merino, G., Muguet, J. B., Bush, D., Piedrahita, R. H., Conklin, D. E. (2002): Morphological development and allometric growth patterns in hatchery-reared California halibut larvae. Journal of Fish Biology, 61, 1217-1229.

Gozlan, R., Copp, G.H., Tourenq, J.N. (1999): Comparison of growth plasticity in the laboratory and field, and implications for the onset of juvenile development in sofie, Chondrostoma toxostoma. Environmental Biology of Fishes, 56, 153-165.

Haddon, M., Willis, J. (1995): Morphometric and meristic comparison of orange roughy (Hoplostethus atlanticus, Trchichthyidae) from the Puysegn Bank and Lord Howe Rise, New Zealand implication for stock structure. Marine Biology, 123, 19 - 27.

Hashemi, S. A., Eskandary, G. H., Sedaghat, S. (2012): Length-weight relationships of Silurus triostegus (Heckel, 1843) from Shadegan Wetland in Khuzestan Province (Iran). American-Eurasian Journal of Agriculture and Environmental Sciences, 12, 1335-1338.

Higgs, D. M., Fuiman, L. A. (1996): Light intensity and schooling behaviour in larval gulf menhaden. Journal of Fish Biology, 48, 979-991.

Hora, S. L., Misra, K.S. (1943): On a small collection of fish from Iraq. Journal of the Asiatic Society of Bengal, Science, 9, 1-15.
Hussain, N. A., Ali, T. S. (2006): Trophic nature and feeding relationships among Al Hammer marsh fishes, southern Iraq. Marsh Bulletin, 1, 9-18

Hussain, N. A., Saoud, H.A., Al-Shami, E.J. (2008): Species composition and ecological indices of fishes in the restored marshes of southern Mesopotamia. Marsh Bulletin, 3, 17-31

Hussein, S. D., Al-Daham, N. K., Al-Kanaani, S. M. (2000a): Monthly variation in feeding activities and feeding intensities of three sympatric native cyprinids and introduced common carp in Al-Hammar Lake, South of Iraq. Basrah Journal of Agricultural Sciences, 13, 39-48.

Hussein, S. D., Al-Daham, N. K., Al-Kanaani, S. M. (2000b): Dietary overlap between the common carp Cyprinus carpio L. and three native cyprinids in Al-Hammar Lake, Southern Iraq. Journal of Basrah Researches, 25, 73-83.

Isaev, V. A., Mikhailova, M. V. (2009): The hydrology, evolution, and hydrological regime of the mouth area of the Shatt al-Arab River. Water Resources, 36, 380-395.

Kovac, V., Copp, G.H. (1999): Morphometry of the stone loach Barbatula barbatula (L.). Do metric characters reflect the species' life history threshold? Environmental Biology of Fishes, 56, $105-115$.

Kemp, P., Bertness, M. D. (1984): Snail shape and growth rates: evidence for plastic shell allometry in Littorina littorea. Evolution, 81, 811-813.

Kumar, S. P., Narvekar, J., Nuncio, M., Kumar, A., Ramaiah, N., Sardesai, S., Gauns, M., Fernanades, V., Paul, J. (2010): Is the biological productivity in the Bay of Bengal light limited? Current Science, 98, 1331-1339.

Lashari, P. K., Narejo, N. T., Mastoi, A. M., Mahar, M. A. (2004): Some morphometric characters and their relationship in carp, Cirrhinus reba (Hamilton) from fishpond district Jacobabad, Sindh. Proceeding of Pakistan Congress of Zoology, 24, 179-184.

Liao, J. C. (2007): A review of fish swimming mechanics and behaviour in altered flows. Philosophical Transactions of the Royal Society B-Biological Sciences, 362, 1973-1993.

Lindsey, C. C. (1988): Factors controlling meristic variation. In: Fish Physiology, Vol. 11, Part B (Hoar, W. S., Randall, D. J., eds.), pp. 197-274. San Diego, CA: Academic Press.

Pelletier, D., Dutil, J. D., Blier, P., Guderley, H. (1994): Relation between growth rate and metabolic organization of white muscle, liver and digestive tract in cod, Gadus morhua. Journal of Comparative Physiology B, 164,179-190.

Masuda, R., Tsokamoto, K. (1996): Morphological development in relation to phototaxis and rheotaxis in the striped jack, Pseudocaranx dentex. Marine and Freshwater Behaviour and Physiology, 28, 75-90.

Matthews, W. J. (1988): Morphology, habitat use, and life history. In: Patterns in freshwater fish ecology. Chapman \& Hall, New York, 756 pp.

McLaughlin, R. L., Grant, J. W. A. (1994): Morphological and behavioural diferences among recently-emerged 
brook charr, Salvelinus fontinalis, foraging in slow- vs. fast-running water. Environmental Biology of Fishes, 39, 289-300.

Meyer, A. (1987): Phenotypic plasticity and heterochrony in Cichlasoma managuense (Pisces, Cichlidae) and their implication for speciation in cichlid fishes. Evolution, 41, 1357-1369.

Minos, G., Katselis, G., Kaspiris, P., Ondrias, I. (1995): Comparison of the change in morphological pattern during the growth in length of the grey mullets Liza ramada and Liza saliens from western Greece. Fisheries Research, 23, 143-155.

Miyazaki, T., Shiozawa, S., Kogane, T., Masuda, R., Maruyama, K., TsokamotoK. (2000): Developmental changes of the light intensity threshold for school formation in the striped jack, Pseudocaranx dentex. Marine Ecology Progressive Series, 192, 267-275.

Naderloo, R. (2011): Grapsoid crabs (Decapoda: Brachyura: Thoracotremata) of the Persian Gulf and the Gulf of Oman. Zootaxa, 3048, 1-43.

Naderloo, R., Schubart, C.D. (2009). Redescription and mitochondrial identification of Chiromantes boulengeri (Calman, 1920) (Decapoda: Brachyura: Sesarmidae) based on fresh material from the Persian Gulf, Iran. Zootaxa, 2128, 61-68.

Najafpour, N. (1997): Identification of some freshwater fishes of Khuzestan Province. Fisheries Research Centre of Khuzestan Province, Iranian Fisheries Research and Training Organisation, Tehran. 96 pp. In Farsi.

Narejo, N. T. (2010): Morphometric characters and their relationship in Gudusia chapra (Hamilton) from Keenjhar lake (Distt: Thatta), Sindh. Pakistan Journal of Zoology, 42, 101-104.

Narejo, N. T., Jafri, S. I. H., Shaikh, S. A. (2000): Studies on the age and growth of Gudusia chapra (Clupiedae: Teleosteii) from the Keenjhar lake (Distt. Thatta) Sindh. Pakistan Journal of Zoology, 32, 307-312.

Oniye, S.J., Adebote, D.A., Usman, S.K., Makop, J.K. (2006): Some aspects of the biology of Protopterus annectens (Owen in Jachi Dam near Katsina, Nigeria. Journal of Fisheries and Aquatic Science, 1, 136-141.

Osse, J. W., van den Boogaart, J. G. M., van Snik, G.M.J., van der Sluys, L. (1997): Priorities during early growth of fish larvae. Aquaculture, 155, 249-258

Rowi ski, P. K., Mateos-Gonzalez, F., Sandblom, E., Jutfelt, F., Ekström, A., Sundström, F. (2015): Warming alters the body shape of European perch Perca fluviatilis. Journal of Fish Biology, 87, $1234-1247$

Sabadin, D., González-Castro, M., ludica, C., Díaz de Astarloa, J.M., Fernández Iriart,e P.J. (2010): Morphometric and genetic assessment of the Cynoscion guatucupa population structure from Buenos Aires coast, Argentine sea. Review of the Biological Marine Oceanography, 45, 513-517.

Safie, A., Khan, A.A., Khan, M.Z. (2014): Study of some mor- phometric and meristic characters of striped piggy fish, Pomadasys stridens (Forsskal, 1775) from Karachi Coast, Pakistan. Journal of Zoological Studies, 1, 1-6.

Sajina, M., Chakraborty, S. K., Hakraborty, A. K., Sudheesan, D. (2013): Morphometric and meristic analyses of horse mackerel, Megalaspis cordyla (Linnaeus, 1758) populations along the Indian coast. Indian Journal of Fisheries, 60, 27-34.

Samaee, S. M., Patzner, R. A. (2010): Morphometric differences among populations of Tuini, Capoeta damascina (Teleostei: Cyprinidae), in the interior basins of Iran. Journal of Applied Ichthyology, 27, 928-933.

Sfakianakis, D. G., Leris, I., Laggis, A., Kentouri, M. (2011): The effect of rearing temperature on body shape and meristic characters in zebrafish (Danio rerio) juveniles. Environmental Biology of Fishes, 92,197-205.

Slavik, O., Horky, P. (2012): Diel dualism in the energy consumption of the European catfish Silurus glanis. Journal of Fish Biology, 81, 2223-2234.

Stearns, S. C. (1983): A natural experiment in life-history evolution: field data on the introduction of mosquitofish (Gambusia affinis) to Hawaii. Evolution, 37, 601-617.

Sunuma, T., Amano, M., Yamanome, T., Furukawa, K., Yamamori, K. (2007): Self-feeding activity of a pleuronectiform fish, the barfin flounder. Aquaculture, 270, 566-569.

Turan, C. (2004): Stock identification of Mediterranean horse mackerel Trachurus mediterraneus using morphometric and meristic characters ICES Journal of Marine Science, 61, $774-781$.

Ünlü, E., Bozkurt, R. (1996): Notes on the catfish, Silurus triostegus (Siluridae) from the Euphrates River in Turkey. Cybium, 20, 315-317.

Ünlü, E., De er, D., Cicek, T. (2012): Comparison of morphological and anatomical characters in two catfish species, Silurus triostegus Heckel, 1843 and Silurus glanis L., 1758 (Siluridae, Siluriformes). North-Western Journal of Zoology, 8, 119-124.

Van Snik, G. M. J., Van Den Boogaart, J. G. M., Osse, J. W. M. (1997): Larval growth patterns in Cyprinus carpio and Clarias gariepinus with attention to the finfold. Journal of Fish Biology, 50, 1339-1352.

Verep, B., Turan, D., Kovac, V. (2006): Preliminary results on morphometry of babel (Barbus tauricus, Kessler, 1877) in the streams of Riza and Artvin province (Turkey). Turkih Journal of Fisheries and Aquatic Sciences, 6, 17-21.

Wimberger, P. H. (1992): Plasticity of fish body shape. The effects of diet, development, family and age in two species of Geophagus (Pisces; Cichlidae). Biological Journal of Linnean Society, 45,197-218.

Zhan, Q.B., Wang, X.L. (2012): Elliptic Fourier analysis of the wing outline shape of five species of antlion (Neuroptera: Myrmeleontidae: Myrmeleontini). Zoological Studies, 51, 399-405. 